\title{
Potential antibacterial activity of some Saudi Arabia honey
}

\author{
Ahmed G. Hegazi ${ }^{1}$, Faiz M. Al Guthami ${ }^{2}$, Ahmed F. M. Al Gethami ${ }^{2}$, Fyrouz M. Abd Allah ${ }^{3}$, Ashraf A. Saleh ${ }^{3}$ and \\ Ehab A. Fouad ${ }^{4}$ \\ 1. Department of Zoonotic Diseases, National Research Centre, Dokki, Giza, Egypt; 2. Al Guthami foundation, \\ Saudi Arabia; 3. Department of Parasitology, National Research Centre, Dokki, Giza, Egypt; 4. Department of \\ Microbiology and Immunology, National Research Centre, Dokki, Giza, Egypt. \\ Corresponding author: Ahmed G. Hegazi, e-mail: ahmedhegazi128@gmail.com, \\ Co-authors: FMA: faiz58@hotmail.com, AFMA: hmd38777@hotmail.com,FMAA: fayrouzabdallah363@gmail.com, \\ AAS: ashrafalfarik@yahoo.com, EAF: ehabfoaud@gmail.com \\ Received: 21-09-2016, Accepted: 17-01-2017, Published online: 21-02-2017
}

doi: 10.14202/vetworld.2017.233-237 How to cite this article: Hegazi AG, Al Guthami FM, Al Gethami AFM, Allah FMA, Saleh AA, Fouad EA (2017) Potential antibacterial activity of some Saudi Arabia honey, Veterinary World, 10(2): $233-237$.

\begin{abstract}
Aim: The aim of this study was to investigate the potential antibacterial activity of some Saudi Arabia honey against selected bacterial strains of medical importance.

Materials and Methods: A total of 10 Saudi Arabia honey used to evaluate their antimicrobial activity against some antibiotic-resistant pathogenic bacterial strains. The bacterial strains were Staphylococcus aureus, Streptococcus pyogenes, Klebsiella pneumoniae, Escherichia coli, and Pseudomonas aeruginosa.
\end{abstract}

Results: The antibacterial activity of Saudi honey against five bacterial strains showed different levels of inhibition according to the type of honey. The overall results showed that the potential activity was differing according to the pathogen and honey type.

Conclusion: It could be concluded that the Saudi honey inhibit the growth of bacterial strains and that honey can be used as complementary antimicrobial agent against selected pathogenic bacteria.

Keywords: antibiotic-resistant, potential antibacterial activity, Saudi Arabia honey.

\section{Introduction}

The microbial resistance to antibiotics and chemicals has been increased worldwide against harmful microorganisms $[1,2]$.

Honey has been used as the oldest sweeter since ancient times as a nutritive as well as effective remedy $[3,4]$, antibacterial [5-8], also honey is recognized as an effective antimicrobial agent used topically in the treatment of burns and wounds [9-12], dyspepsia, peptic ulcer $[13,14]$ and gastritis [15-17], and liver disease [18].

The biological properties of honey play an important role due to its floral source [19]. There are several factors attributed to antimicrobial activity of honey $[17,20,21]$ as endogenous hydrogen peroxide content [11,22], inhibin [23] which acts as antibacterial factor other than $\mathrm{H}_{2} \mathrm{O}_{2}$ [24], hydrogen peroxide [25], osmotic effect of honey, the low $\mathrm{pH}[20,26]$, defensin-1, as well as the presence of phytochemical factors [27,28], phytochemical components $[17,24,29,30]$. Some of the phytochemical components of honey could stimulate monocytes to release cytokines as interleukin (IL)-1 and IL-6, tumor

\footnotetext{
Copyright: Hegazi, et al. Open Access. This article is distributed under the terms of the Creative Commons Attribution 4.0 International License (http://creativecommons.org/licenses/by/4.0/), which permits unrestricted use, distribution, and reproduction in any medium, provided you give appropriate credit to the original author(s) and the source, provide a link to the Creative Commons license, and indicate if changes were made. The Creative Commons Public Domain Dedication waiver (http://creativecommons.org/ publicdomain/zero/1.0/) applies to the data made available in this article, unless otherwise stated.
}

necrosis factor-alpha, which modulate the immune response to overcome the infection [4,31,32]. The antibacterial activity of different honey was studied by many several authors [6,7,8,20,21,33-36], many honey are available in the Saudi market either locally produced by Saudi beekeepers or imported from different countries $[8,35,36]$. A comparison between Saudi Arabia honey and Egyptian honey was previously studied by Hegazi [7].

Thus, this investigation was evaluated the potential antibacterial activity of 10 Saudi Arabia honey against some bacterial strains of medical importance.

\section{Materials and Methods}

\section{Ethical approval}

Experiments were performed according to the Guide for the care and use of Laboratory animals and Ethical Approval of Animal Rights according to Committee, National Research Centre, Egypt.

\section{Bacterial strains}

Five pathogenic bacterial strains have antibiotic-resistant. Gram-positive and Gram-negative were used. The Gram-positive bacteria were including Staphylococcus aureus (ATCC 25923) and Streptococcus mutans. The S. mutans strain was provided with Cairo Microbiological Resources Center (Cairo MIRCEN). The Egypt Microbial Culture Collection number for the $S$. mutans is $1815^{\mathrm{T}}$ where the Gram-negative bacteria included Klebsiella pneumoniae (ATCC 27736), Escherichia coli (ATCC 35218) and Pseudomonas aeruginosa (ATCC 27853). 


\section{Honey}

Fresh 10 Saudi honey samples (1 kg each) were kindly provided by Alnahal Aljwal Company, 2015 flowering season). The monofloral honey harvested from apiaries (From Authorized proved apiary farm of Alnahal Aljwal, Saudi Arabia), these honey are vended as "monofloral" meaning that the honey must derive from at least $55 \%$ of pollen from a single floral source according to Louveaux et al. [37]. The collected honey samples were Shafallah honey (Capparis spinosa), acacia (Acacia nilotica) honey, Astragalus honey (Astragalus pelecinus), Talh honey (Thymus vulgaris), Sidr honey (Ziziphus spina-christi), spring Lena honey (Rhanterium epapposum), large influx honey (Acacia tortilis), olive (Alaatm) honey (Olea europaea), Dahbianh honey (Carduus acicularis), and Citrus honey (Citrus sinensis). Each honey sample was collected in a sterile universal glass container and kept at $2-8^{\circ} \mathrm{C}$ until tested. Physiological saline $\mathrm{PBS}$ pH 7.2 was used for all dilution steps under aseptic condition according to the method described by Nzeako and Hamdi [38]. Evaluations of the antibacterial activity of different honey dilution were performed according to Hegazi and Allah [7,39]. The results of antibacterial activity against different examined bacteria were determined.

\section{Antibacterial assays}

Five bacterial strains were used: $S$. aureus (ATCC 25923), S. mutans $\left(1815^{\mathrm{T}}\right), K$. pneumoniae (ATCC 27736), E. coli (ATCC 35218), and P. aeruginosa (ATCC 27853). The bacterial suspension was adjusted by comparison of $0.5 \mathrm{Mc}$-Farland turbidity standards $\left(5 \times 10^{7}\right.$ cells $\left./ \mathrm{ml}\right)$. Then, it was further diluted to obtain a final of $5 \times 10^{6}$ cells $/ \mathrm{ml}$. These bacterial strains were enriched on selective broth for bacterial propagation [40]. In a separate tube containing $40 \mu \mathrm{l}$ of $21.30 \%$ honey [34] concentration mixed with $0.20 \mu \mathrm{l} / 10 \mathrm{ml}$ from inarched broth of each propagated S. aureus, S. mutans, K. pneumoniae, E. coli, and $P$. aeruginosa. These tubes were incubated at $37^{\circ} \mathrm{C}$ for $24 \mathrm{~h}$. The growths of control bacterial strains as well as inhibitions of the bacterial growth due to mixed with honey were measured by turbidity at $420 \mathrm{~nm}$ wavelength. The mean values of inhibition were calculated from triple reading in each test [7].

\section{Statistical analysis}

Data were analyzed statistically using student "T" test showing mean + standard deviation. Data were compared using one-way. Statistical significance was accepted at $\mathrm{p}<0.01$ according to Zar [41].

\section{Results}

The results of the different Saudi honey induced growth inhibition of $S$. aureus, $S$. mutans, K. pneumoniae, E. coli, and $P$. aeruginosa were illustrated Table-1 and Figure-1. All honey types at concentration of $20.30 \%$ showed inhibition of different bacterial growth. The efficiency of Tetracycline $(50 \mu \mathrm{g})$ was indicated that the inhibition of $S$. aureus $(0.253 \pm 0.001)$ and $S$. mutans $(0.371 \pm 0.001)$, K. pneumonia (0.362 \pm 0.001$)$, E. coli $(0.396 \pm 0.002)$, and $P$. aeruginosa $(0.351 \pm 0.001)$.

The honey inhibition of $S$. aureus ranged from $0.299 \pm 0.003$ to $0.621 \pm 0.001$ and $S$. mutans ranged from $0.317 \pm 0.001$ to $0.595 \pm 0.002$. The highest inhibition of $S$. aureus against Dahbianh honey was $0.299 \pm 0.003$ and the highest inhibition of $S$. mutans against Talh honey was $0.371 \pm 0.001$, where the lowest inhibition of $S$. aureus against Spring Lena honey was $0.299 \pm 0.003$ and the lowest inhibition of $S$. mutans against olive (Alaatm) honey was $0.595 \pm 0.002$.

The highest antibacterial activity was determined in Spring Lena honey $(0.381 \pm 0.031)$ against $K$. pneumonia, while Shafallah honey $(0.398 \pm 0.001)$ against $E$. coli but Citrus honey $(0.382 \pm 0.003)$ against $P$. aeruginosa, where the lowest activity was observed in Dahbianh honey $(0.551 \pm 0.001)$ against $K$. pneumonia, while Olive (Alaatm) honey $(0.634 \pm 0.014)$ against $E$. coli but large influx honey $(0.595 \pm 0.001)$. It was clear that all honey types induced an inhibitory activity of the growth of different pathogens. This reduction depends on the type of honey.

\section{Discussion}

The investigation into antibacterial activity of Saudi honey from different sources of 5 pathogenic

Table-1: Results of efficacy of different honeys types against pathogenic bacteria.

\begin{tabular}{lccccc}
\hline Bacteria antibacterial agent & S. aureus & S. mutans & K. pneumonia & E. coli & P. aeruginosa \\
\hline Normal bacterial growth & $1.721 \pm 0.001$ & $1.807 \pm 0.002$ & $1.746 \pm 0.001$ & $1.528 \pm 0.011$ & $1.601 \pm 0.002$ \\
Tetracycline $(50 \mu \mathrm{g})$ & $0.253 \pm 0.001$ & $0.271 \pm 0.001$ & $0.362 \pm 0.001$ & $0.396 \pm 0.002$ & $0.351 \pm 0.001$ \\
Shafallah honey & $0.384 \pm 0.015$ & $0.424 \pm 0.001$ & $0.404 \pm 0.002$ & $0.398 \pm 0.001$ & $0.494 \pm 0.001$ \\
Acacia honey & $0.440 \pm 0.001$ & $0.353 \pm 0.011$ & $0.421 \pm 0.031$ & $0.532 \pm 0.012$ & $0.435 \pm 0.012$ \\
Astragalus honey & $0.394 \pm 0.002$ & $0.345 \pm 0.014$ & $0.383 \pm 0.001$ & $0.402 \pm 0.001$ & $0.467 \pm 0.001$ \\
Talh honey & $0.445 \pm 0.002$ & $0.317 \pm 0.001$ & $0.461 \pm 0.014$ & $0.399 \pm 0.002$ & $0.549 \pm 0.002$ \\
Sidr honey & $0.497 \pm 0.003$ & $0.359 \pm 0.001$ & $0.501 \pm 0.001$ & $0.411 \pm 0.011$ & $0.411 \pm 0.011$ \\
Spring Lena honey & $0.621 \pm 0.001$ & $0.491 \pm 0.001$ & $0.381 \pm 0.031$ & $0.499 \pm 0.001$ & $0.462 \pm 0.012$ \\
Large influx honey & $0.394 \pm 0.002$ & $0.444 \pm 0.002$ & $0.533 \pm 0.001$ & $0.501 \pm 0.002$ & $0.595 \pm 0.001$ \\
Olive (Alaatm) honey & $0.425 \pm 0.002$ & $0.595 \pm 0.002$ & $0.451 \pm 0.014$ & $0.634 \pm 0.014$ & $0.579 \pm 0.002$ \\
Dahbianh honey & $0.299 \pm 0.003$ & $0.347 \pm 0.003$ & $0.551 \pm 0.001$ & $0.432 \pm 0.012$ & $0.411 \pm 0.011$ \\
Citrus honey & $0.319 \pm 0.013$ & $0.414 \pm 0.011$ & $0.439 \pm 0.016$ & $0.558 \pm 0.001$ & $0.382 \pm 0.003$ \\
\hline
\end{tabular}

S. aureus=Staphylococcus aureus, E. coli=Escherichia coli, P. aeruginosa=Pseudomonas aeruginosa,

K. pneumonia=Klebsiella pneumonia 


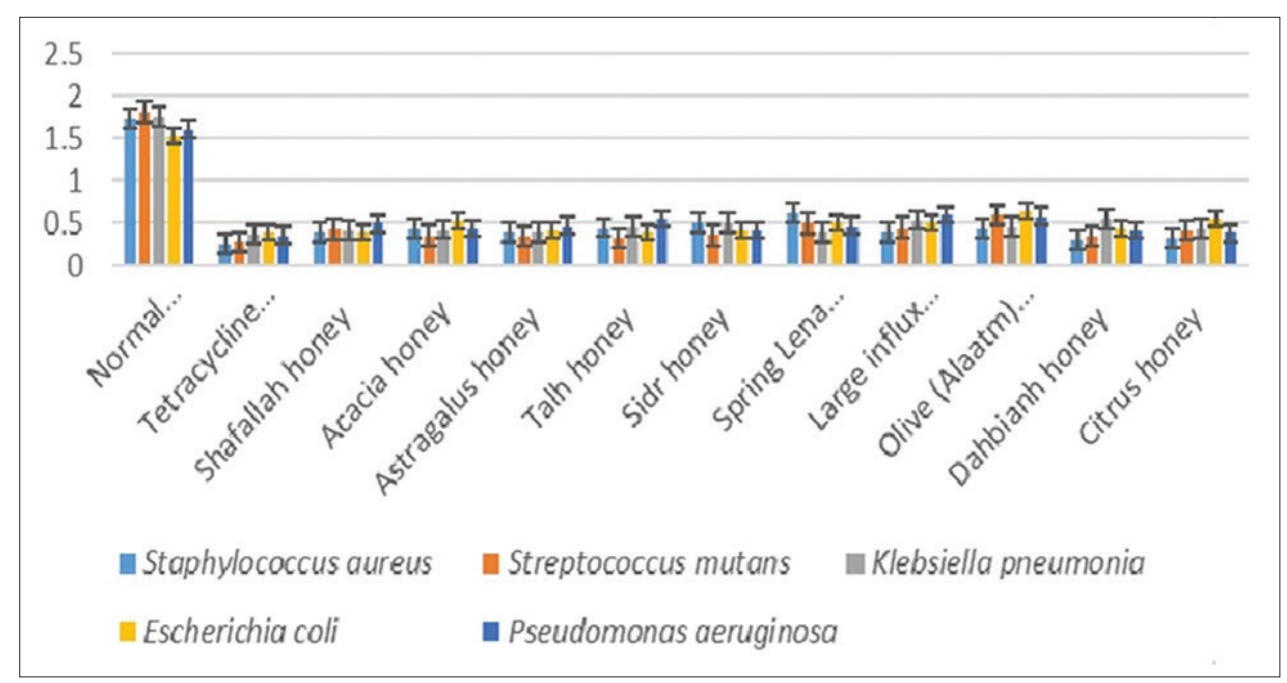

Figure-1: Results of efficacy of different honey types against pathogenic bacteria.

bacteria was recorded in Table-1 and Figure-1.20.30\% honey concentration from different types showed inhibition of five bacterial growths. The inhibition of these bacteria may depend on the type of honey origin. These results were attributed to the floral source of honey which acts an important role on its biological properties [19]. The antimicrobial activity of honey also return to several factors $[17,20,21]$ as osmotic effect of honey [20,26,42]. Acidity of honey $(\mathrm{pH}$ range from 3.2 to 4.5 ) or activity of glucose oxidase in the ripening of nectar [43]. The presence of hydrogen peroxide $[44,45]$, endogenous hydrogen peroxide content [11,22], inhibin [23] which acts as antibacterial factor other than $\mathrm{H}_{2} \mathrm{O}_{2}$ [24], hydrogen peroxide [25], non-peroxide substances [46,47], defensin-1, as well as the presence of phytochemical factors $[27,28]$ and phytochemical components $[17,24,29,30]$. The antibacterial activity of different honey was studied by several authors [5-8,20,21,33-36,48].

Comparison between Manuka honey with ling heather honey was determined by Lu Hodgeson [49] who found that whereas $S$. aureus and P. aeruginosa were inhibited by both honey. While, ling heather honey was inhibited E. coli, Proteus mirabilis and Streptococcus faecalis, on the other hand, yet Manuka honey was inhibited E. coli, P. mirabilis and S. faecalis. Media containing various concentrations of honey was evaluated against Gram-positive and Gram-negative bacteria [16] and they found that most pathogenic bacteria failed to grow in honey at a concentration of $40 \%$ or above. Hegazi and Allah [8] found that honey samples with different Saudi honey, were effective antibacterial against different examined pathogenic bacteria. Several honey available in the Saudi market especially the locally produced Shaoka, and Taify Sidr, in addition to imported Yemeni Sidr, black seed, clover and orange blossom are as potent as Manuka honey [36]. Furthermore, 10 honey samples collected from different floral areas around Riyadh were investigated [3]. 9 widely used honey in Saudi Arabia (Yemeni Sidr, Taify Sidr, Kashmiri Sidr,
Shaoka, Somra, Black Seed, Black Forest, and Clover honey), and Manuka honey against E. coli, P. aeruginosa, Salmonella enterica serovar Typhimurium, Shigella flexneri and $K$. pneumoniae, S. aureus, and Streptococcus pyogenes were examined by Halawani and Shohayeb [35]. The most sensitive Gram-negative bacterium was $P$. aeruginosa while the most sensitive Gram-positive bacterium was and S. pyogenes [36]. Honey from some countries as Manuka honey from Australia, heather honey from the United Kingdom, and locally marketed Indian honey was detected their antibacterial activity [50]. Honey obtained from Izmir proved more effective as inhibitors against $P$. aeruginosa, E. coli and S. aureus, where the honey obtained from Muğla exhibited high anticandidal activity on C. albicans [22].

Finally, we could have concluded that the variations in the activity of different honey were attributed to the previously mentioned factors which influenced the antibacterial activity [7] as osmotic properties of honey $[20,39]$; honey $\mathrm{pH}$ or activity of glucose oxidase [41]; hydrogen peroxide $[42,45]$, non-peroxide substances [46,47], presence of propolis which contain flavonoid [46], and volatile antibacterial substances [40].

\section{Conclusion}

From the current results, it concluded that the Saudi honeys inhibit the growth of bacterial strains and that honey can be used as complementary antimicrobial agent against selected pathogenic bacteria.

\section{Authors' Contributions}

$\mathrm{AGH}$, give the idea, share as well as supervise on practical work, editing and help publishing of the article. FMA and AFMA, provided some materials and help in editing the article. FMAA, AAS and EF. They make isolation and identification and do the practical work, help during editing and publishing of the article. All authors have read and approved the final manuscript. 


\section{Acknowledgments}

The authors are grateful for the financial support by the National Research Center of Egypt under registration number $12 / 5 / 1$ and Al Guthami Foundation, Saudi Arabia.

\section{Competing Interests} interests.

The authors declare that they have no competing

\section{References}

1. Wright, G.D. (2007) The antibiotic resisted: The nexus of chemical and genetic diversity. Nat. Rev. Microbiol., 5: $175-186$.

2. Byarugaba, D.K. (2009) Mechanisms of antimicrobial resistance cited. In: Sosa, A.D.J., Byarugaba, D.K., AmabileCuevas, C.F., Hsueh, P.R., Kariuki, S. and Okeke, I.N., editors. Antimicrobial Resistance in Developing Countries. Ch. 2. Springer Science + Business Media, LLC. p15-16. DOI: 10.1007/978-0-387-89370-9 2.

3. Ayaad, T.H., Shaker, G.H. and Almuhnaa, A.M. (2009) Isolation of antibacterial peptides from Saudi Arabian honeybees and investigating the antimicrobial properties of natural honey samples. Egypt. Acad. J. Biol. Sci., 2(2): 23-34.

4. Alvarez-Suarez, J.M., Tulipani, S., Romandini, S., Bertoli, E. and Battino, M. (2010) Contribution of honey in nutrition and human health: A review. Med. J. Nutr. Metab., 3: 15-23.

5. Wilkinson, J.M. and Cavanagh, H.M. (2005) Antibacterial activity of 13 honeys against Escherichia coli and Pseudomonas aeruginosa. J. Med. Food, 2: 100-103.

6. Chute, R.K., Deogade, N.G. and Kawale, M. (2010) Antimicrobial activity of Indian honey against clinical isolates. Asiatic J. Biotechnol. Resour., 1: 35-38.

7. Hegazi, A.G. (2011) Antimicrobial activity of different Egyptian honeys as comparison of Saudi Arabia Hone. Res. J. Microbiol., 6(5): 488-495.

8. Hegazi, A.G. and Abd Allah, F.M. (2012) Antimicrobial activity of different Saudi Arabia honeys. Glob. Vet., 9(1): 53-59.

9. Toussoun, Z., Rashed, A. and Hegazi, A.G. (1997) Honey and propolis as management of some chronic skin ulcers. Proceeding of International Symposium on Apitherapy, Cairo 8-9 $9^{\text {th }}$, March, 1997. p71.

10. Subrahmanyam, M., Hemmady, A. and Pawar, S.G. (2001) Antibacterial activity of honey on bacteria isolated from wounds. Ann. Burns Fire Disasters, 14: 198-201.

11. Brudzynski, K. (2006) Effect of hydrogen peroxide on antibacterial activities of Canadian honeys. Can. J. Microbiol., 52: 1228-1237.

12. Fakoor, M. and Pipelzadeh, M.H. (2007) A study on the healing effect of honey on infected open fracture wounds. Pak. J. Med. Sci., 23: 327-329.

13. Tumin, N., Halim, N.A., Shahjahan, M., Noor, I.N., Sattar, M.A., Khan, A.H. and Mohsin, S.S. (2005) Antibacterial activity of local Malaysian honey. Malays. $J$. Pharm. Sci., 3: 1-10.

14. Kumar, K.P., Bhowmik, D., Biswajit, C. and Chandira, M.R (2010) Medicinal uses and health benefits of honey: An overview. J. Chem. Pharm. Res., 2(1): 385-395.

15. Eteraf-Oskouei, T. and Najafi, M. (2013) Traditional and modern uses of natural honey in human diseases: A review. Iran. J. Basic Med. Sci., 16(6): 731-742.

16. Hussain, M.B., Hannan, A., Akhtar, N., Fayyaz, Q.G., Imran, M., Saleem, S. and Qureshi, I.A. (2015) Evaluation of the antibacterial activity of selected Pakistani honeys against multi-drug resistant Salmonella typhi. BMC Complement. Altern. Med., 15: 32.

17. Halawani, E.M. (2006) A study on Salmonella typhimurium causing food poisoning in Al-Taif city and antibacterial effect of Nigella sativa honey and Camels urine. Ph.D
Thesis. Taif University, Saudi Arabia.

18. Ajibola, A., Chamunorwa, J.P. and Erlwanger, K.H. (2012) Nutraceutical values of natural honey and its contribution to human health and wealth. Nutr. Metab., 9: 61.

19. Molan, P. (2002) Not all honeys are the same for wound healing. Bull. Eur. Tissue Rep. Soc., 9: 5-6.

20. Molan, P.C. (1992) The antibacterial activity of honey. 1. The nature of the antibacterial activity. Bee World, 73: 5-28.

21. Kwakman, P.H., Te Velde, A.A., De Boer, L., Speijer, D.V., Enbroucke-Grauls, C.M. and Zaat, S.A. (2010) How honey kills bacteria. FASEB J., 24: 2576-2582.

22. Mercan, N., Guvensen, A., Celik, A. and Katircioglu, H. (2007) Antimicrobial activity and pollen composition of honey samples collected from different provinces in Turkey. Nat. Prod. Res., 21(3): 187-195.

23. Nour, M.E. (1988) Some Factors Affecting Quality of Egyptian Honeys. Ph. D. Thesis. Faculty of Agriculture, Cairo University.

24. Irish, J., Blair, S. and Carter, D.A. (2011) The antibacterial activity of honey derived from Australian Flora. Otto M, ed. PLoS One, 6(3): e18229.

25. Watt, B.E., Proudfoot, A.T. and Vale, J.A. (2004) Hydrogen peroxide poisoning. Toxicol. Rev., 23: 51-57.

26. Cooper, R.A., Molan, P.C. and Harding, K.G. (2002) The sensitivity to honey of gram-positive cocci of clinical significance isolated from wounds. J. Appl. Microbiol., 93: 857-863.

27. Mandal, M.D. and Mandal, S. (2011) Honey: Its medicinal property and antibacterial activity. Asian Pac. J. Trop. Biomed., 1(2): 154-160.

28. Moniruzzaman, M., Sulaiman, S.A., Khalil, M.I. and Gan, S.H. (2013) Evaluation of physicochemical and antioxidant properties of sourwood and other Malaysian honeys: A comparison with Manuka honey. Chem. Cent. J., 7: 138.

29. Yao, L., Jiang, Y., Singanusong, R., Datta, N. and Raymont, K. (2004) Phenolic acids and abscisic acid in Australian Eucalyptus honeys and their potential for floral authentication. Food Chem., 86: 169-177.

30. Mavric, E., Wittmann, S., Barth, G. and Henle, T. (2008) Identification and quantification of methylglyoxal as the dominant antibacterial constituent of manuka (Leptospermum scoparium) honeys from New Zealand. Mol. Nutr. Food Res., 52(4): 483-489.

31. Tonks, A., Cooper, R.A., Price, A.J., Molan, P.C. and Jones, K.P. (2001) Stimulation of TNF-alpha release in monocytes by honey. Cytokine, 14: 240-242.

32. Tonks, A.J., Cooper, R.A., Jones, K.P., Blair, S.J., Parton, G.H. and Tonks, A. (2003) Honey stimulates inflammatory cytokine production from monocytes. Cytokine, 17: 21-23.

33. Molan, P.C., Coley, K.E., Alsomal, N. and Hancock, B.M. (1994) Susceptibility of Helicobacter pylori to the antibacterial activity of Manuka honey. J. R. Soc. Med., 87: 9-12.

34. Hegazi, A.G., Moharm, N.Z., Abd Allah, F., Nour, M.S. and Khair, A.M. (2002) Antibacterial activity of different Egyptian honeys in relation to some bee products. Egypt. J. Vet. Sci., 36: 31-42.

35. Halawani, E.M. and Shohayeb, M.M. (2011a) Shaoka and Sidr honeys surpass in their antibacterial activity local and imported honeys available in Saudi markets against pathogenic and food spoilage bacteria. Aust. J. Basic Appl. Sci., 5(4): 187-191.

36. Halawani, E.M.A. and Shohayeb, M.M. (2011b) Survey of the antibacterial activity of Saudi and some international honeys. Jpn. Meteorol. Agency, 3(4): 94-101.

37. Louveaux, J., Maurizio, A. and Vorwohl, G. (1978) Methods of melissopalynology. Bee World, 59: 139-157.

38. Nzeako, B. and Hamdi, J. (2000) Antimicrobial potential of honey on some microbial isolates. SQU. J. Sci. Res. Med. Sci., 2: 75-79.

39. Wasfi, R., Elkhatib, W.F. and Khairalla, A.S. (2016) Effects 
of selected Egyptian honeys on the cellular ultrastructure and the gene expression profile of Escherichia coli. PLoS One, 11(3): e0150984.

40. Cruickshank, R., Duguid, J.P., Masion, B.P. and Swain, R.H. (1979) Medical Microbiology. 12 $2^{\text {th }}$ ed. Churchill Livingstone, Edinburgh, London, New York.

41. Zar, J.H. (1999) Biostatistical Analysis. Prentice Hall, New Jersey, USA. p663.

42. Feás, X., Iglesias, A., Rodrigues, S. and Estevinho, L.M. (2013) Effect of Erica sp. Honey against microorganisms of clinical importance: Study of the factors underlying this biological activity. Molecules, 18(4): 4233-4246.

43. Sherlock, O., Dolan, A., Athman, R., Power, A., Gethin, G., Cowman, S. and Humphreys, H. (2010) Comparison of the antimicrobial activity of Ulmo honey from Chile and Manuka honey against methicillin-resistant Staphylococcus aureus, Escherichia coli and Pseudomonas aeruginosa. BMC Complement. Altern. Med., 10: 47.

44. Roth, L.A., Kwan, S. and Sporns, P. (1986) Use of a disc assay system to detect oxytetracycline residues in honey. J. Food Prot., 49(6): 436-441.

45. Nassar, H.M., Li, M. and Gregory, R.L. (2012) Effect of honey on Streptococcus mutans growth and biofilm formation. Appl. Environ. Microbiol., 78(2): 536-540.

46. Sufya, N., Matar, N., Kaddura, R. and Zorgani, A. (2014) Evaluation of bactericidal activity of Hannon honey on slowly growing bacteria in the chemostat. Drug Healthc. Patient Saf., 6: 139-144.

47. Zainol, M.I., Mohd Yusoff, K. and Mohd Yusof, M.Y. (2013) Antibacterial activity of selected Malaysian honey. BMC Complement. Altern. Med., 13: 129.

48. Erejuwa, O.O., Sulaiman, S.A. and Wahab, M.S.A. (2012) Honey - A novel antidiabetic agent. Int. J. Biol. Sci., 8(6): 913-934.

49. Lu, J., Carter, D.A., Turnbull, L., Rosendale, D., Hedderley, D., Stephens, J., Gannabathula, S., Steinhorn, G., Schlothauer, R.C., Whitchurch, C.B. and Harry, E.J. (2013) The effect of New Zealand Kanuka, Manuka and clover honeys on bacterial growth dynamics and cellular morphology varies according to the species. PLoS One, 8(2): e55898.

50. Mullai, V. and Menon, T. (2007) Bactericidal activity of different types of honey against clinical and environmental isolates of Pseudomonas aeruginosa. J. Altern. Complement. Med., 13(4): 439-442. 